\title{
Understanding Firms' Corporate Social Activity Choice Decisions: A Conceptual Framework
}

\author{
Goitom Tesfom ${ }^{1} \&$ Nancy J. Birch ${ }^{2}$ \\ ${ }^{1}$ Department of Management, Eastern Washington University, Bellevue, WA, USA \\ ${ }^{2}$ Department of Accounting and Information Sciences, Eastern Washington University, Cheney, WA, USA \\ Correspondence: Goitom Tesfom, Department of Management, Eastern Washington University, Bellevue, \\ Washington, USA. E-mail: gtsegay@ewu.edu
}

Received: September 12, $2014 \quad$ Accepted: October 10, $2014 \quad$ Online Published: November 24, 2014

doi:10.5539/ijms.v6n6p14

URL: http://dx.doi.org/10.5539/ijms.v6n6p14

\begin{abstract}
It has been long observed that firms make choices among corporate social activities. However there is limited research that shows how firms make those choice decisions and what factors determine the outcome. This paper intends to help fill the gap. Based on the insights from the literature review, the authors suggest a conceptual framework that identifies the factors that would drive a firm's corporate social activity choice. From these factors the authors advance research propositions that discuss the potential relationships with corporate social activity choice decisions, suggest methods and provide a questionnaire that could be a useful tool for further research. Further research can focus on the empirical validation of the suggested research framework and testing the propositions in the off-shoring/outsourcing context.
\end{abstract}

Keywords: CSR, CSR activity choice, CSR goals, CSR priorities, outsourcing; off-shoring

\section{Introduction}

Corporate social responsibility (CSR) is the "organization's obligation to maximize its positive impact and minimize its negative effects in being a contributing member to society, with concern for society's long-term needs and wants" (Lantos, 2001, p. 600). Furthermore the literature points out that those CSR-focused businesses would proactively promote the public interest by encouraging community growth and development, and voluntarily eliminating practices that cause harm in the public sphere, regardless of legality (Bomann-Larsen \& Wiggen, 2004). However the last three decades have witnessed a lively debate over the role of corporations in society (Basu \& Palazzo, 2008). A couple of decades ago Freeman \& Liedtka, (1991) observed that the idea of corporate social responsibility has failed to help create the good society. Moreover several writers characterize CSR as less than successful at seriously addressing real issues of sustainable business practices (Porter \& Kramer, 2006; Visser \& Crane, 2010; Ludescher \& Mahsud, 2010). While some of the criticisms are directed at the looseness and generality of the CSR concept, others blame the firm's ineffectiveness in identifying, prioritizing, and addressing the social issues that matter most. This paper deals with the latter criticism.

Hidden in the latter criticism are questions about how firms choose or prioritize one corporate social activity over the other and what factors matter most in their choices. CSR programs can be an effective way to achieve numerous environmental, social, stakeholder voluntarism and economic goals within a corporation (Dahalsrud 2006; Caroll 1979, 1991). But with so many approaches to CSR available, there is limited knowledge on how executives championing corporate social responsibility often prioritize and choose among CSR activities. Hence the paper intends to address three basic objectives:

1) To suggest a conceptual framework that identifies the possible goals/ factors that would drive a firm's corporate social activity choice decisions and examine and understand how firms choose or prioritize between CSR activities.

2) To advance research propositions that discusses the potential relationships between firms CSR goals and corporate social activity choice decisions.

3) To suggest a research method and a questionnaire useful for further research. 


\section{Literature Review}

The intended conceptual framework focuses on corporate social activity prioritization and choice of offshoring/outsourcing firms in the United States. However the framework could also be adapted to countries in Western Europe (e.g., UK, France and Germany) where offshoring/outsourcing activities by local firms received negative review (Whitfield, 2007). While outsourcing refers to having work for a company done by another organization, offshoring refers specifically to having this work done for the company by another organization located in another country (Gupta et al., 2007). This paper focuses on outsourcing/offshoring operations that lead to loss of jobs in the USA. Due to the increasing interest of the general United States public in employment, education and the overall economic situation, the practice of offshore/outsourcing is under renewed scrutiny. Hence, focus on CSR practices of USA offshoring/outsourcing firms not only answers the question about how offshoring/outsourcing firms choose or prioritize their corporate social activities but also provides more information and knowledge on off-shoring/ outsourcing.

Due to the negative impact of firm closures by off shoring/outsourcing firms in the US on employment opportunities in the US, one can easily conclude that supporting laid off workers should be the primary corporate social responsibility of US offshoring/outsourcing firms. Because of the many interrelated business benefits that can be derived from increased employee engagement (i.e., more loyalty, improved recruitment, supporting market demand, protecting the firm from damaging negative publicity and so on), understanding the CSR activities that are important to employees is usually the first company priority. However out of more than 800 US firms engaged in offshoring/outsourcing activities, according to Lou Dobbs exporting America website, only a few (e.g. Cisco and IBM) have training programs to help the laid-off workers in the US add new skills to their résumés and prepare for jobs of the future (Weidenbaum, 2005). Moreover Tesfom and Birch (2008) found that, overall; US offshoring/outsourcing firms place low priority on supporting the employees they laid-off in the US. On the contrary, the authors also found that US offshoring/outsourcing firms place high priority to contributing to charities and education. Hence the central question is why do offshoring/ outsourcing firms place higher priority on contributing to charities and education than helping the employees they laid-off. How do firms choose or prioritize between CSR activities?

The issue under discussion specifically deals with a theory of stakeholder salience that can explain to whom and to what managers actually pay attention. The theory of stakeholder salience (Savage, Nix, Whitehead, \& Blair 1991; Harrison \& St. John, 1994; Mitchell, Agle, \& Wood, 1997) permits the explicit recognition of situational uniqueness and managerial perception to explain how managers prioritize stakeholder relationships. In their analysis Mitchell, Agle and Wood (1997) proposed that stakeholders possess some combination of three critical attributes: power, legitimacy, and urgency. Accordingly, the critical attributes predict that the salience of a particular stakeholder to the firm's management is low if only one attribute is present, moderate if two attributes are present and high if all three attributes are present. Moreover the authors emphasize that the manager's perception of a stakeholder's attributes is critical to the manager's view of stakeholder salience.

Despite the general dominance of the Mitchell, Agle and Wood (1997) framework, there is relatively little agreement on which stakeholder group criteria best help describe managers' prioritization. One of the major controversies is about whether salience is a separate criterion or a summation of power, urgency and legitimacy (Gago \& Antolin, 2004). Parent and Dephouse (2007) conclude that power and legitimacy are more important than salience. Moreover Mattingly (2004) argues that urgency precedes power and legitimacy.

According to Carroll (1979), a firm's choice of corporate social activity follows its definition of corporate social responsibility. Hence corporate social responsibility may be different for different companies. Some of these definitions may include financial performance (Friedman, 1970; Hillman \& Keim, 2001), corporate social performance (Carroll, 1979; Wood, 1991), corporate strategic fit of CSR to company activities (Porter \& Kramer, 2006), the firm's CSR Management Capacity (Jaeger 2009; Husted 2003), meeting CSR reporting requirements (O'Riordan, 2000, Nehme \& Wee, 2008), regulatory compliance (Carroll, 1979), and/or fulfilling of management interest (Mitchell, Agle, \& Wood, 1997). According to Carroll once firms define their corporate social responsibility they identify the corporate social activity to which these responsibilities are tied, such as consumerism, environment, employment discrimination, product safety, occupational safety and health, etc. Although the above summary of definitions adopted by different firms may help us to understand how firms choose or prioritize their corporate social activities, there is a need to develop a robust theoretical framework based on empirically tested propositions.

Figure 1 shows the relationship between firm's corporate social activity choice drivers and possible corporate social activity choices. The framework is based on Carroll's (1979) argument that, a firm's choice of corporate 
social activity follows its definition of corporate social responsibility. Hence a firm may define its CSR in any of the five CSR drivers. Accordingly that definition guides the choices of the corporate social activities listed to CSR drivers. However the conceptual framework also considers the influence of the firm's internal CSR management capacity and its industry on the firm's corporate social activity choice decisions.

The firm's internal CSR management capacity influences both corporate social activity choice and corporate social activity management. When CSR activities are managed internally enterprises can organize their CSR activities in different ways. While some companies create an internal structure and assign the job to senior management, others assign line management to the job. Moreover an affiliated foundation could be assigned to manage the whole CSR project of the firm. It is also possible that firms do not formally assign anyone to the job but rather the activity becomes an integral part of day today of operations of the business. The latter shows the firm's lower commitment to the CSR project. When CSR activities are managed externally the firms can make simple donations that do not involve commitment to a specific project or may engage in joint management of a project with the external party.

Corporate social activity choices of firms may also be influenced by industry type (Figure 1). According to Smith (1991) heavy manufacturing companies involved in smelting and chemical production are more closely monitored for environmental performance than companies in other industries. Moreover, after the recession that started in 2008, the financial industry is more strictly monitored for its ethical standards than any other industry (Verschoor, 2010). It is also possible that some industries undertake more corporate social activities than do other industries. According to the Danish labor market authority (2005) enterprises in the real property/business services industry were least likely to have implemented CSR activities, while enterprises in transport and manufacturing are most likely to have done so.

Although the paper would be of greater interest if it were to provide a rationalization that would lead us to expect a particular outcome or cluster of outcomes over another, it is not realistic to do that as firms in different industries can use different social activities to achieve different CSR goals. What is important is, to show the link between the firm's corporate social responsibility goal and the corporate social activities it has selected within the firm's industry context. The relationship between questions 4 and 7, question 4 and 8 , and question 4 and 9 in the attached questionnaire highlights the importance of such argument. Hence researchers are expected to identify a cluster of corporate social activities that firms in the industry under investigation use to achieve their specific social goals. Hence acknowledging the influence of firms' management capacity and industry type on firms' CSR activity choice decisions, the next section discusses the link between firm's corporate social activity (goal) drivers and corporate social activity choices (Figure 1) and advances testable research propositions.

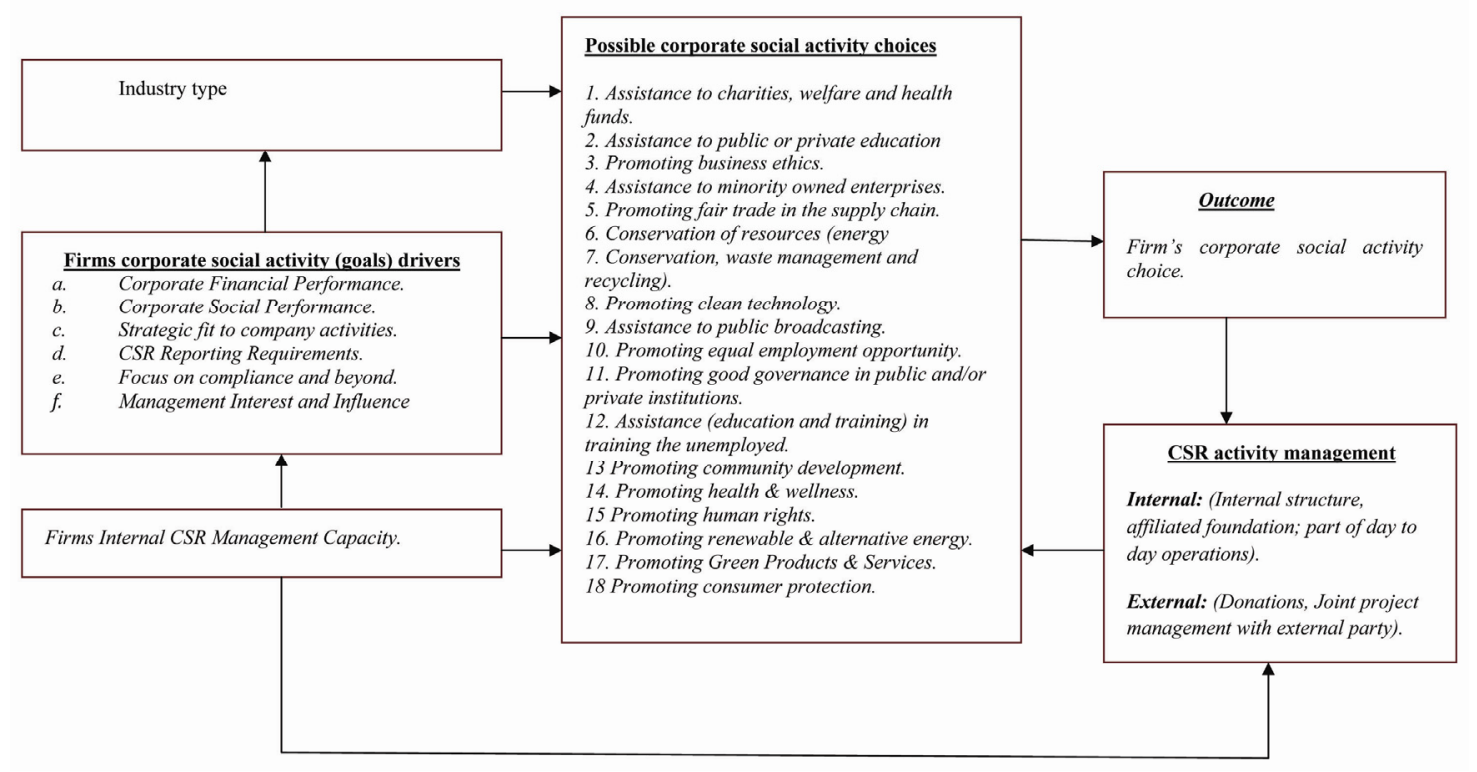

Figure 1. A framework of understanding firms corporate social activity choice decisions 


\section{Relationship between Firm's Corporate Social Responsibility (Goals) Drivers and Firms Corporate Social Activity Choice Decisions}

\subsection{Corporate Financial Performance}

The corporate Financial Performance definition of corporate social responsibility is based on the premise that the purpose of CSR is to conduct the business in accordance with shareholders' desires, which generally will be to make as much money as possible while conforming to the basic rules of society, both those embodied in law and those embodied in ethical custom (Friedman, 1970). Moreover Friedman argues that managerial attention to interests other than those of investors is a breach of trust that inevitably reduces the welfare of shareowners. Thus firms are obliged to choose the social activity that increases the shareholder value of the firm's financial performance. However the relationship between the firm's corporate social activity and its impact on the firm's financial performance is not without nuisance. So far CSR research has failed to establish a satisfying link between corporate social responsibility (CSR) and corporate financial performance (CFP) (Akpinar et al., 2008; McWilliam \& Siegel, 2001; Margolis \& Walsh, 2001). Moreover comparisons between the financial performance of corporations and their levels of CSR involvement were conducted (Cochran \& Wood, 1984; Weissman, 1984; Aupperle, Carroll, \& Hatfield, 1985), with mixed results. The controversy involves problems of measurement, direction of relationships and existence of causal relationships. Leaving the debate aside, the principle of corporate financial performance (CFP) is based on the premise that CSR engagement should be limited to the corporate social activities that positively influence the firm's financial performance. According to Hillman and Keim (2001), building good relations with primary stakeholders often leads to increased financial returns. Hence Hillman and Keim (2001) conclude that whereas primary stakeholder management can lead to shareholder wealth creation, participation in social issues does not have the same kind of result. Thus, it is likely that firms that promote the CFP perspective prioritize their corporate social activities based on the activities' contributions to the firm's financial performance. The forgoing discussion leads us to the propositions below.

P1. A positive relationship exists between firms focus on corporate financial performance and firm's corporate social activity priority.

\subsection{Corporate Social Performance}

CSP can be defined as 'a business organization's configuration of principles of social responsibility, processes of social responsiveness, and policies, programs, and observable outcomes as they relate to the firm's societal relationships (Wood, 1991a, p. 693). From a stakeholder theory perspective, corporate social performance can thus be assessed in terms of a company meeting the demands of its multiple stakeholder groups, and companies must seek to satisfy their demands "as an unavoidable cost of doing business" (Ruf et al., 2001, p. 143). In contrast to CFP, CSP may pursue social issues that may not create financial returns to the firm. Carroll's "Three-dimensional Conceptual Model" (Carroll, 1979, 1991) was the initial model of corporate social performance (CSP). It consisted of an integration of three aspects: first, a definition of social responsibility; second, an identification of the social issues to which these responsibilities are tied, and third, the philosophy of responsiveness. Hence, according to the CSP perspective, firms prioritize their investment on corporate social activities based on the activities' importance to firms' corporate social performance or level of social impact on stakeholders (Akpinar et al., 2008; Ruf et al., 2001, Wood \& Jones, 1995). Consequently it is likely that we see a relationship between the firm's focus on corporate social performance and the firm's corporate social activity choice or priority.

P2. A positive relationship exists between a firm's focus on corporate social performance and a firm's Corporate social activity priority.

\subsection{Strategic Fit to Company Activities}

Strategic responsibilities imply engaging in socially responsible activities only when they are expected to benefit both the company and one or more stakeholder groups. Porter and Kramer (2006) argue that each company must select issues that intersect with its particular business. For instance various businesses including Green Mountain Coffee, Starbucks and Caribou coffee have claimed adopting procurement of Fair Trade tea and coffee. Weyerhaeuser, lumber company, has been cooperating with Habitat for Humanity to build homes for the poor. Accordingly, Porter and Kramer explain that other social agendas that do not fit to the company's strategy are best left to those companies in other industries, Non-Governmental Organizations (NGOs), or government institutions that are better positioned to address them. The authors argue that the essential test that should guide CSR is not whether a cause is worthy but whether it presents an opportunity to create shared value - that is, a meaningful benefit for society that is also valuable to the business. The strategic fit criterion differs from CSP in a sense that for greater social impact the social activity should be aligned to what the firm does or its strategy. Hence it is more 
likely that a company's prioritization of corporate social activity is related to the relevance of the particular corporate social activity to the firm's strategy.

P3. A positive relationship exists between firm's alignment of CSR to its strategy and its corporate social activity priority.

\subsection{Firms Internal CSR Management Capacity}

According to Jaeger (2009), availability of internal staff and resources to manage the CSR program and its effectiveness can influence a company's definition of CSR. Jaeger argues that the more credible efforts tend to be led by key players within a company. For instance a firm that lacks expertise in the area of community development may define CSR as charitable donations rather than project-based social activities which are often classified as more amenable to assessment and impact judgment. This way, a company will be relieved from human and financial obligations, which could require planning and monitoring actual projects. Corporate philanthropy does not need much of an effort, on the organization's part, except writing a check and leaving the rest to the NGOs. Moreover firms that have corporate foundations may be able to engage in project-based corporate social activities than companies without corporate foundations. Thus based on the availability of internal resources and management capacity a firm has three basic options for defining or overseeing CSR activities: the contribution - where firms simply donate to an external usually non-governmental or non-profit agency; the internalization option, where the firm sets up a wholly internal arm to give effect to its charitable impulses; and the collaboration, seen as half-way between the two, where a firm contributes to an external 'expert', but joins it in managing the way benefit is derived from its funding (Husted 2003). Hence it is more likely that company prioritization of corporate social activity is related to the firm's definition of CSR in relation to its internal CSR Management Capacity.

P4. A positive relationship exists between a firm's internal CSR Management Capacity and a firm's Corporate social activity priority.

\subsection{CSR Reporting Requirements}

Taking responsibility for its impact on society means first and foremost that a company must account for its actions. Social accounting, a concept describing the communication of social and environmental effects of a company's economic actions to particular stakeholders and to society at large, is thus an important element of CSR. In the last decade, there has been tremendous growth in CSR rating agencies that assess corporations based on their social and environmental performance (O'Riordan, 2000; Nehme \& Wee, 2008). Some of the agencies are socially responsible investors (SRI), including the well-known social indices of KLD, FOOTSE4good, and the Dow Jones Sustainability Index. These rating agencies receive considerable attention in the media and among businesses, as people across the economic spectrum analyze corporate behavior beyond financial performance. Corporations themselves seek out this information when they wish to measure their social impact and assess their long-term value beyond quarterly performance. Ratings are also relevant to a broad array of stakeholders, including investors, consumers, employees, communities, activists, and the broader public.

Rating agencies vary widely, depending on the audience they serve and the criteria used to assess performance. Hence a number of reporting guidelines or standards have been developed to serve as frameworks for social performance accounting. The requirements can be different for different firms and as a result many companies report on issues that don't necessarily matter to consumers, and then neglect the important ones. Hence a firm's efforts to comply with reporting norms may serve as criteria for selecting which social activities a firm chooses to be involved.

P5. A positive relationship exists between corporate social responsibility reporting requirements and firm's corporate social activity priority.

\subsection{Focus on Compliance and Beyond}

The existence, survival and profitability of a company depend on the fulfillment of legal responsibilities. If a company does not comply with the law either it will be subject to penalties such as fines, which impair its profitability, or it will be prohibited from operating (Carroll, 1979). Traditionally Human Resources Management (HRM) and CSR functions have been led by the need for compliance with new employment laws and with environmental, ethical and social issues. Many companies are prioritizing their compliance initiatives in strategies, plans and budgets for several reasons, including the impact of compliance on these new broader initiatives and the costs associated with noncompliance. Proactive compliance has also become an image and brand issue, with consumers becoming more conscious of compliant and socially responsible companies. This perspective advocates that corporations that comply with society's legal sanctions are being socially responsible. 
Given the focus on compliance, the role of independent mediators, particularly the government, in ensuring that corporations are prevented from harming the broader social good, including people and the environment, could serve as criteria for the firm's choice of social activities. Moreover firms that define CSR in line with the compliance perspective are more likely to focus on remedying issues that the government suggested as a weakness. Hence it is more likely that a firm's definition of CSR as a compliance based response and a firm's choice or prioritization of its corporate social activity are related.

P6. A positive relationship exists between a firm's focus on CSR compliance regulations and a firm's corporate social activity priority.

\subsection{Directed towards Management Interest and Influence}

The principle of managerial discretion functions on an individual level and emphasizes managers' responsibilities to behave as moral actors and make choices about activities designed to achieve socially responsible outcomes (Wood, 1991). Hence to be included in the organization's policies and programs, it is critical that the social and environmental issues first secure management's attention. Managerial attention may focus on shareholder objectives above the interests of other stakeholders (Amihud \& Lev, 1981). Stakeholder theory, in contrast, emphasizes the firm's relations with a wider range of implicitly and explicit stakeholders (Donaldson \& Preston, 1995; Jones, 1995; Jones \& Wicks, 1999). The theory of stakeholder salience (Mitchell, Agle, \& Wood 1997) emphasizes that the manager's perception of a stakeholder's attributes is critical to the manager's view of stakeholder salience. In this research the authors argue that manager's special interest in some group of stakeholders over others may be based on the manager's background and interest. For example, a manager who comes from low socio-economic background is more likely to initiate projects that benefit the poor than other managers. Moreover a manager who is proud of his/her educational achievement is more likely to give back to the college or university from which he or she graduated. A manager who values the environment is more likely to guide the firm's corporate social activity to the protection of the environment. A manager's choice of corporate social activities can be influenced by his/her cultural background. In their cross cultural study Ibrahim and Parsa (2005) find a difference in management orientation toward legal and ethical responsibilities between American and French managers. According to the study while American managers are highly oriented toward legal and ethical responsibilities, French managers focus on economic and philanthropic responsibilities. Moreover according to Kusku and Fraser (2004), compared to Turkish corporations, Australian corporations were more likely to obey the law but less likely to do the voluntary activities. Hence, a firm's CSR that is at the discretion and interest of management may influence the firm's choice of corporate social activity.

P7. A positive relationship exists between management's interest in Corporate Stake holders and the firm's corporate social activity priority.

\section{Suggested Method}

\subsection{Sample}

To test the hypotheses, among other sources, the study can use an exhaustive survey of 800 offshoring/outsourcing firms in the US listed in "CNN's Lou Dobbs Tonight". Lou Dobbs lists the companies in his website (http://www.cnn.com/CNN/Programs/lou.dobbs.tonight/popups/exporting.america/content.html). An email with the link to the survey could be sent to all 800 companies. Follow up reminders could be sent to increase the response rate and to minimize non-response bias. Lou Dobb's exporting America website does not provide the contact addresses of the offshore outsourcing companies, and researchers need to compile and verify company e-mail addresses by visiting each company website. Hence the authors of this paper believe that the data collection process requires a formidable research budget that compensates the human labor required to do the job right.

\subsection{Questionnaire Design}

The questionnaire may contain six sections (see attached suggested questionnaire). The first section may consist of demographic questions in which the respondents are asked to indicate their job title and their company's industry classification. Section two could ask respondents to rate agreement with the purpose of social activity goals. Section three could ask respondents to indicate which social activities the firm is involved in. Section four could ask respondents to rate CSR criteria in terms of importance using a 7-point scale. In part five, respondents could be asked to rate several CSR activities in terms of their company's involvement using a 7 point scale. The final section could ask respondents to rank the top seven areas to which their company devotes the most resources.

The questionnaire is built by the authors from scratch. Hence, to measure Validity and reliability of the 
questionnaire, it needs to be pretested on a sample of companies that are part of the target population and feedback could be used to modify the questionnaire in order to minimize respondent error. In addition to the use of frequency tables and descriptive statistics to summarize the results, regression analyses and chi-square tests of independence can be useful to test the hypotheses and to determine if significant relationships exist between variables of interest, as hypothesized.

\section{Conclusion}

At a time when several writers characterize CSR as less than successful at seriously addressing real issues of sustainable business practices (Porter \& Kramer, 2006; Visser \& Crane, 2010; Ludescher \& Mahsud, 2010), it is high time to understand how firms make CSR choice decisions. Hence the purpose of this research is to suggest a conceptual framework that identifies goals/ factors that would drive a firm's corporate social activity choice decisions and understand how firms choose or prioritize between CSR activities. According to Maignan \& Ferrell, (2000) and later Dahalsrud (2006) CSR programs can be an effective way to achieve numerous environmental, social, stakeholder, voluntarism and economic goals within a corporation. However most of the current research in the area focuses on the relationships between corporate social responsibilities (CSR) and corporate financial performance (Cambell, 2007). There is limited research devoted to understanding the relationship between CSR drivers and corporate social responsibility choice decisions (Galbreath, 2010). The good news is that recent external pressures from influential stakeholders are pushing firms to create more comprehensive systems and processes to manage their economic, social and environmental performance. Hence the future of the research on examining the relationship between corporate social responsibility drivers and firms' corporate social activity choice decisions is bright and the authors of this paper encourage others to delve into these topics further. The authors hope that the conceptual framework in this research will serve as a potential new theoretical idea that encourages future research.

\section{Managerial Implications}

It is widely accepted in the CSR literature that corporations can better achieve their business objectives by acting more responsibly. But what is missing in the CSR practice is a way to evaluate the effectiveness and credibility of the company's CSR initiative choice decisions. This is mainly because there is no information on how companies identify the CSR initiatives. The realty is with so many approaches to CSR available, executives championing sustainability often don't know which one to choose. Hence understating firm's CSR initiative choice decisions will help management practitioners not only to identify the initiative that is most likely to be effective and useful for the company and the social cause it intends to advance, but also to develop a criteria useful to evaluate the effectiveness and credibility of the CSR initiative. By doing that management practitioners can clearly demonstrate the impact of the specific CSR initiative in measurable terms. The evaluation outcomes will also help corporate leaders in their decision to allocate resources among the different company CSR initiatives.

\section{Suggested Original Questionnaire}

\section{Part I: Demographic Questions}

1. Please indicate your job title within the organization by circling one of the following numbers:

[1] Chair/Chief Executive

[2] Director/Partner

[3] Senior Management

[4] Middle Management

[5] Junior Management

[6] Other? Please specify

2. Please indicate your company's primary industry classification by circling one of the following numbers:

[1] Code 11. Agriculture, Forestry, Fishing and Hunting

[2] Code 21. Mining, Quarrying, and Oil and Gas Extraction

[3] Code 22. Utilities

[4] Code 23. Construction

[5] Code 31-33. Manufacturing

[6] Code 42. Wholesale Trade 
[7] Code 44-45. Retail Trade

[8] Code 48-49. Transportation and Warehousing

[9] Code 51. Information

[10] Code 52. Finance and Insurance

[11] Code 53. Real Estate and Rental and Leasing

[12] Code 54. Professional, Scientific, and Technical

[13] Code 55. Management of Companies and Enterprises

[14] Code 56. Administrative and Support, and Waste Management and Remediation Services

[15] Code 61. Educational Services

[16] Code 62. Health Care and Social Assistance

[17] Code 71. Arts, Entertainment, and Recreation

[18] Code 72. Accommodation and Food Services

[19] Code 81. Other Services (except Public Administration)

[20] Code 92. Public Administration

[21] Other, please specify

\section{Part II}

3. Do you have a Corporate Social Responsibility (CSR) activity goal currently (201x-201x)?

Please circle: [1] YES [2] NO

(If your answer to question 3 is "NO", please skip question 4 and proceed to question 5.)

4. If your answer to question 3 is YES, please indicate what your corporate social activity goal is designed to do by circling the appropriate number for each goal ( $1=$ strongly disagree, $7=$ strongly agree):

Contribute to your company's financial performance

$[1] \quad[2] \quad[3] \quad[4] \quad[5] \quad[6] \quad[7]$

Contribute to your company's corporate social performance

$[1] \quad[2] \quad[3] \quad[4] \quad[5] \quad[6] \quad[7]$

Achieve strategic fit to your company's core business activities

$[1] \quad[2] \quad[3] \quad[4] \quad[5] \quad[6] \quad[7]$

Fit to your firm's internal CSR management capacity

$[1] \quad[2] \quad[3] \quad[4] \quad[5] \quad[6] \quad[7]$

Respond to CSR reporting requirements

$[1] \quad[2] \quad[3] \quad[4] \quad[5] \quad[6] \quad[7]$

Comply to CSR legal requirements and beyond

$[1] \quad[2] \quad[3] \quad[4] \quad[5] \quad[6] \quad[7]$

Satisfy your management's interest and influence

$[1] \quad[2] \quad[3] \quad[4] \quad[5] \quad[6] \quad[7]$

\section{Part III}

5. Is your company involved in CSR activities currently (201x-201x)?

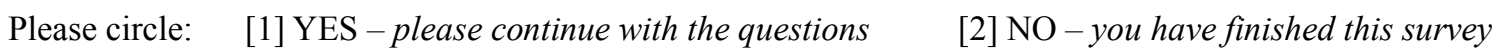

6. Please indicate whether your company has done any of the following as part of its CSR activity by circling the appropriate response:

Donated resources to an external party

[1] YES [2] NO

Developed a non-foundation internal structure to manage CSR projects

[1] YES [2] NO

Contributed to an external 'expert' while joining in the management of the activity [1] YES [2] NO

Established a foundation to manage its social activities

[1] YES [2] NO

\section{Part IV}

7. Please rate each of the CSR criteria below relative to its importance to your corporate social activity choice by circling the appropriate number for each ( $1=$ not at all important, $7=$ extremely important):

Impact of the CSR activity on your company's financial performance

$[1] \quad[2] \quad[3] \quad[4] \quad[5] \quad[6] \quad[7]$

Contribution of the CSR activity to your company's corporate social performance 


\section{$[1][2] \quad[3] \quad[4] \quad[5] \quad[6] \quad[7]$}

Strategic fit of the CSR activity with your company's core business activities

$[1] \quad[2] \quad[3] \quad[4] \quad[5] \quad[6] \quad[7]$

Consistency of the CRS activity with your company's internal CSR management capacity

$[1] \quad[2] \quad[3] \quad[4] \quad[5] \quad[6] \quad[7]$

Consistency of the CSR activity with your company's CSR reporting requirements

$[1][2] \quad[3] \quad[4] \quad[5] \quad[6] \quad[7]$

Consistency of the CSR activity with your company's focus on compliance and beyond

$[1] \quad[2] \quad[3] \quad[4] \quad[5] \quad[6] \quad[7]$

Consistency of the CSR activity with your company's management interest and influence

$[1] \quad[2] \quad[3] \quad[4] \quad[5] \quad[6] \quad[7]$

Part V

8. Please rate each of the CSR activities listed below by circling the number that best reflects your company's level of involvement in each ( $1=$ not involved, $7=$ always involved):

Assistance to charities, welfare and health funds [1] [2] [3] [4] [5] [6] [7]

Assistance to public or private education [1] [2] [3] [4] [5] [6] [7]

Promoting business ethics [1] [2] [3] [4] [5] [6] [7]

$\left.\begin{array}{lllllll}\text { Assistance to minority owned enterprises } & {[1]} & {[2]} & {[3]} & {[4]} & {[5]} & {[6]}\end{array}\right]$

Promoting fair trade in the supply chain [1] [2] [3] [4] [5] [6] [7]

Conservation of resources (energy, waste and recycling) $[1] \quad[2] \quad[3] \quad[4] \quad[5] \quad[6]$ [7]

Promoting clean technology $[1] \quad[2] \quad[3] \quad[4] \quad[5] \quad[6] \quad[7]$

Assistance to public broadcasting [1] [2] [3] [4] [5] [6] [7]

Promoting equal employment opportunity $[1] \quad[2] \quad[3] \quad[4] \quad[5] \quad[6] \quad[7]$

Promoting good governance in public and private institutions $[1] \quad[2] \quad[3] \quad[4] \quad[5] \quad[6] \quad[7]$

Assisting in training the unemployed [1] [2] [3] [4] [5] [6] [7]

Promoting community development [1] [2] [3] [4] [5] [6] [7]

Promoting health \& wellness $\quad[1] \quad[2] \quad[3] \quad[4] \quad[5] \quad[6] \quad[7]$

Promoting human rights $[1] \quad[2] \quad[3] \quad[4] \quad[5] \quad[6] \quad[7]$

Promoting renewable \& alternative energy $[1] \quad[2] \quad[3] \quad[4] \quad[5] \quad[6] \quad[7]$

$\left.\begin{array}{lllllll}\text { Promoting green products \& services } & {[1]} & {[2]} & {[3]} & {[4]} & {[5]} & {[6]}\end{array}\right]$

Promoting consumer protection $[1] \quad[2] \quad[3] \quad[4] \quad[5] \quad[6] \quad[7]$

\section{Part VI}

9. Please rank the top seven areas to which your company has devoted the most resources and effort to in the last five years. Assign a rank of 1 to the CSR activity that your company devoted the most resources and effort. Assign a rank of 2 to the CSR activity that your company devoted the second most resources and effort. Continue until a rank of 7 has been assigned.

Assistance to charities, welfare and health funds

Assistance to public or private education

Promoting business ethics

Assistance to minority owned enterprises.

Promoting fair trade in the supply chain

Conservation of resources

Promoting clean technology 
Assistance to public broadcasting

Promoting equal employment opportunity

_ Promoting good governance in public and/or private institutions

__ Assisting in training the unemployed

_ Promoting community development

_ Promoting health \& wellness

_ Promoting human rights

_ Promoting renewable \& alternative energy

__ Promoting green products \& services

Promoting consumer protection

\section{References}

Akpinar, A., Jiang, Y., Gomez-Mejia, L. R., Berrone, P., \& Walls, J. L. (2008). Strategic Use of CSR as a Signal for Good Management. IE Business School Working paper.

Amihud, Y., \& Lev, B. (1981). Risk Reductions as a Managerial Motive for Conglomerate Mergers. Bell Journal of Economics, 12(2), 605-617. http://dx.doi.org/10.2307/3003575

Aupperle, K., Carroll A., \& Hatfield, J. (1985). An empirical examination of the relationship between corporate social responsibility and profitability. Academy of Management Journal, 28(2), 446-463. http://dx.doi.org/10.2307/256210

Basu, K., \& Palazzo, G. (2008). Corporate Social Responsibility: A Process Model of Sensemaking. Academy of Management Review, 33(1), 122-136. http://dx.doi.org/10.5465/AMR.2008.27745504

Bomann-Larsen, L., \& Wiggen, O. (2004). Responsibility in world business: Managing harmful side-effects of corporate activity. Tokyo: United Nations University Press.

Campbell, J. L. (2007). Why would corporations behave in socially responsible ways? An institutional theory of corporate social responsibility. The Academy of Management Review, 32(3), 946-967. http://dx.doi.org/10.5465/AMR.2007.25275684

Carroll, A. B. (1979). A Three-Dimensional Conceptual Model of Corporate Social Performance. Academy of Management Review, 4(4), 497-505.

Carroll, A. B. (1991). The Pyramid of Corporate Social Responsibility: Toward the Moral Management of $\begin{array}{lllll}\text { Organizational Stakeholders. } & \text { Business } & \text { Horizons, } & \text { 34(4), }\end{array}$ http://dx.doi.org/10.1016/0007-6813(91)90005-G

Cochran, P. L., \& Wood, R. A. (1984). Corporate social responsibility and financial performance. Academy of Management Journal, 27(1), 42-56. http://dx.doi.org/10.2307/255956

Dahlsrud, A. (2006). How corporate social responsibility is defined: an analysis of 37 definitions. Corporate Social Responsibility and Environmental Management.

Danish Labour Market Authority. (2005). Erfaringsopsamling vedrørende inddragelsen afandre aktører $i$ beskcftigelsesindsatsen. Main Report, Ramboll, Management/Arbejdsmarkedsstyrelsen, Denmark.

Donaldson, T., \& Preston, L. E. (1995). The stakeholder theory of the corporation: Concepts, evidence, implications. Academy of Management Review, 20(1), 65-91.

Friedman, M. (1970). The Social Responsibility of Business Is to Increase Its Profits. New York Times Magazine, 13 September.

Gago, R. F., \& Antolìn, M. N. (2004). Stakeholder salience in corporate environmental strategy. Corporate Governance, 4(3), 65-76. http://dx.doi.org/10.1108/14720700410547512

Galbreath, J. (2010). Drivers of Corporate Social Responsibility: the Role of Formal Strategic Planning and Firm Culture. British Journal of Management, 21(2), 511-525.

Gupta, A., Seshasai, S., Mukherji, S., \& Ganguly, A. (2007). Offshoring: the transition from economic drivers toward strategic global partnership and 24-hour knowledge factory. Journal of Electronic Commerce in Organizations, 5(2), 1-22. http://dx.doi.org/10.4018/jeco.2007040101 
Harrison, J. S., \& St. John, C. H. (1994). Strategic management of organizations and stakeholders. Minneapolis/St. Paul, MN: West Publishing.

Hillman, A. J., \& Keim, G. D. (2001). Shareholder value, stakeholder management, and social issues: what's the bottom line? Strategic Management Journal, 22(2), 125-139. http://dx.doi.org/10.1002/1097-0266(200101)22:2<125::AID-SMJ150>3.0.CO;2-H

Husted, B. W. (2003). Governance choices for corporate social responsibility: To contribute, collaborate, or internalize? Long Range Planning, 36(5), 481-498. http://dx.doi.org/10.1016/S0024-6301(03)00115-8

Ibrahim, N. A., \& Parsa, F. (2005). Corporate Social Responsiveness Orientation: Are there Differences between U.S and French Managers? Review of Business, 26(1), 27-33.

Jaeger, J. (2009). Choosing Among a Vast Array of CSR Initiatives. Compliance Week, 60(69), 60-70.

Jones, T. M. (1995). Instrumental stakeholder theory: a synthesis of ethics and economics. Academy of Management Review, 20(2), 404-437.

Jones, T. M., \& Wicks, A. C. (1999). Convergent Stakeholder Theory. Academy of Management Review, 24(2), 206-221.

Kusku, F., \& Zarkada-Fraser, A. (2004). An Empirical Investigation of Corporate Citizenship in Australia and Turkey. British Academy of Management, 15(1), 57-72.

Lantos, G. P. (2001). The boundaries of strategic corporate social responsibility. Journal of Consumer Marketing, 18(7), 595-630. http://dx.doi.org/10.1108/07363760110410281

Lou Dobbs Tonight. (2004). Exporting America. Retrieved from www.cnn.com/CNN/Programs/lou.dobbs.tonight/popups/exporting.America

Ludescher, J. C., \& Mahsud, R. (2010). Opening Pandora's Box: Corporate Social Responsibility Exposed. The Independent Review, 15(1), 123-130.

Maignan, I., \& Ferrell, O. C. (2003). Nature of corporate responsibilities: Perspectives from American, French, and German consumers. Journal of Business Research, 56(1), 55-67. http://dx.doi.org/10.1016/S0148-2963(01)00222-3

Mattingly, J. E. (2004). Dissertation Abstract: Stakeholder Salience, Structural Development, and Firm Performance: Structural and Performance Correlates of Sociopolitical Stakeholder Management Strategies. Business and Society, 43(1), 97-114. http://dx.doi.org/10.1177/0007650304263415

Mitchell, R. K., Agle, B. R., \& Wood, D. J. (1997). Toward a theory of stakeholder identification and salience: Defining the principle of who and what really counts. Academy of Management Review, 22(4), 853-886.

Nehme, M., \& Wee, C. (2008). Tracing the Historical Development of Corporate Social Responsibility and Corporate Social Reporting. James Cook University Law Review, 15(1), 198-229.

O'Riordan, T. (2000). On corporate social reporting. Environment and Planning, 32(1), 1-4. http://dx.doi.org/10.1068/a3201com

Parent, M. M., \& Deephouse, D. L. (2007). A case study of stakeholder identification and prioritization by managers. Journal of Business Ethics, 75(1), 1-23. http://dx.doi.org/10.1007/s10551-007-9533-y

Porter, M. E., \& Kramer, M. R. (2006). Strategy and society: The link between competitive advantage and corporate social responsibility. Harvard Business Review, 84(12), 78-92.

Ruf, B. M., Muralidhar, K., Brown, R. M., Janney, J. J., \& Paul, K. (2001). An empirical investigation of the relationship between change in corporate social performance and financial performance: a stakeholder theory perspective. Journal of Business Ethics, 32, 143-156. http://dx.doi.org/10.1023/A:1010786912118

Savage, G. T., Nix T. W., Whitehead, C. J., \& Blair, J. D. (1991). Strategies for Assessing and Managing $\begin{array}{llll}\text { Stakeholders. Academy of } & \text { Management }\end{array}$ http://dx.doi.org/10.5465/AME.1991.4274682

Smith, A. (1991). Wealth of Nations. New York, NY: Prometheus Books.

Tesfom, G., \& Birch, N. (2008). Do offshore outsourcing firms in the USA use their investments on corporate social responsibility to alleviate negative attitudes toward offshore outsourcing?. Social Responsibility Journal, 4(4), 428-438. http://dx.doi.org/10.1108/17471110810909849

Verschoor, C. C. (2010). Are we experiencing an ethics bubble? Strategic Finance, 91(7), 10-13. 
Visser, W., \& Crane, A. (2010). Corporate Sustainability and the Individual: Understanding What Drives Sustainability Professionals as Change Agents. Retrieved from http://ssrn.com/abstract=1559087Visser

Weidenbaum, M. (2005). Outsourcing: pros and cons. Business Horizons, 48(4), 311-315. http://dx.doi.org/10.1016/j.bushor.2004.11.001

Weissman, G. (1984). Social responsibility and corporate success. Business and Society Review, 51, 67-68.

Whitfield, D. (2007). Cost overruns delays and terminations: 105 outsourced public sector ICT projects. European Services Strategy Unit. Retrieved from http:/www.european-services-strategy.org.uk/

Wood, D. J. (1991). Corporate social performance revisited. Academy of Management Review, 16(4), $691-718$.

Wood, D. J., \& Jones, R. E. (1995). Stakeholder mismatching: A theoretical problem in empirical research on corporate social performance. The International Journal of Organizational Analysis, 3(3), 229-267. http://dx.doi.org/10.1108/eb028831

\section{Copyrights}

Copyright for this article is retained by the author(s), with first publication rights granted to the journal.

This is an open-access article distributed under the terms and conditions of the Creative Commons Attribution license (http://creativecommons.org/licenses/by/3.0/). 